\title{
Antitumor and antioxidant status of Galega purpurea root in Ehrlich ascites carcinoma bearing Swiss albino mice
}

\author{
M Gupta $^{1, *}$, UK Mazumder ${ }^{1}$ and P Gomathi ${ }^{2}$ \\ ${ }^{1}$ Department of Pharmaceutical Technology, Jadavpur University, Kolkata-700032, India; ${ }^{2}$ Department of Pharmaceutical \\ Chemistry, ASN Pharmacy College, Tenali, Andhra Pradesh-522201, India
}

\begin{abstract}
SUMMARY
The present study was designed to determine the antitumor and antioxidant properties of methanol extract from the root of Galega purpurea (Papilionaceae) (MEGP) against Ehrlich Ascites Carcinoma (EAC) bearing Swiss albino mice. Acute and short-term toxicity studies were performed initially in order to ascertain the safety of MEGP. The effect of MEGP on the growth of transplantable murine tumor, life span of EAC bearing hosts and simultaneous alterations in the hematological profile and liver biochemical parameters (lipid peroxidation, antioxidant enzymes) were estimated. The MEGP showed decrease in tumor volume, packed cell volume and viable cell count and increases the nonviable cell count and mean survival time thereby increasing life span of EAC tumor bearing mice. Hematological profile reverted to more or less normal levels in extract treated mice. Treatment with MEGP decreased the levels of lipid peroxidation and increased the levels of glutathione, superoxide dismutase and catalase. The results suggested that the methanol extract of Galega purpurea root exhibited antitumor effect by modulating lipid peroxidation and augmenting antioxidant defense system in EAC bearing mice.
\end{abstract}

Key words: Galega purpurea; Antitumor; Antioxidant; Ehrlich ascites carcinoma

\section{INTRODUCTION}

Galega purpurea (Papilionaceae) a plant popularly known as 'kolinji' in Tamil, which thrives throughout China and Southern parts of India. It grows on hard stony ground too difficult to be rooted. The various parts of the plant are widely used in the folk medicine for the treatment of cough, asthma, bilious febrile attacks, arthritis and rheumatism. Decoction of the root useful in the management of enlargement and obstruction of the liver, spleen and kidney. Also the root has been

\footnotetext{
*Correspondence: M Gupta, Division of Pharmacology, Department of Pharmaceutical Technology, Jadavpur University, Kolkata-700032, West Bengal, India. Tel: +913324404123; Fax: +9133 24146967; E-mail: pgoms@yahoo.com
}

reported to be useful in hard tumors, diarrhoea and gonorrhea (Nadkarni, 1976). In view of this and evidence from the existing information show that this plant may possess some important biological activities. But the lack of scientific information about the traditional use, phytochemical, pharmacological and toxicological activities of this plant prompted us to evaluate the in vivo antitumor and antioxidant activity of the methanol extract of Galega purpurea root in Ehrlich Ascites Carcinoma (EAC) tumor bearing Swiss albino mice.

\section{MATERIALS AND METHODS}

\section{Plant material}

The roots of the plant Galega purpurea (Family: 
Papilionaceae) were collected from Erode district of Tamilnadu, India. The plant material was taxonomically identified by Botanical Survey of India, Kolkata. A voucher specimen (No. GMG 03/ 05 ) has been preserved in our laboratory for future reference. The root were dried under shade and then powdered with a mechanical grinder and stored in airtight container. The dried powder material of the root was defatted with petroleum ether and the marc thus obtained was then extracted with methanol in a soxhlet apparatus. The solvent was completely removed under reduced pressure and a semisolid mass was obtained (MEGP, yield 7.3\%). Phytochemical screening of the extract revealed the presence of flavonoids, tannins, alkaloids, glycosides and steroids. The dried MEGP was suspended in normal saline and used for the present study.

\section{Chemicals}

The following chemicals were obtained from the indicated commercial sources: Phenazonium methosulphate (PMS) and Nicotinamide adenine dinucleotide (NADH), thiobarbituric acid (TBA), nitroblue tetrazolium chloride (NBT) (Loba Chemie, Bombay, India); 1-chloro-2,4-dinitro benzene (CDNB), bovine serum albumin (Sigma chemical co., St. Luis, MO, USA); Folin-Ciocalteau phenol, reduced Glutathione and 5,5'-dithio bis-2-nitro benzoicacid (DTNB) (SISCO Research Laboratory, Bombay, India). All the reagents used were of analytical reagent grade.

\section{Animals}

Studies were carried out using male Swiss albino mice weighing $21 \pm 2 \mathrm{~g}$. They were obtained from the animal house of Jadavpur University, Kolkata. The mice were grouped and housed in poly acrylic cages $(38 \times 23 \times 10 \mathrm{~cm})$ with not more than 12 animals per cage and maintained under standard laboratory conditions (temperature $25 \pm 2^{\circ} \mathrm{C}$ ) with dark/ light cycle (14/10 h). They were allowed free access to standard dry pellet diet (Hindustan Lever, Kolkata, India) and water ad libitum. The mice were acclimatized to laboratory conditions for 10 days before commencement of the experiment. All procedures described were reviewed and approved by the University Animal Ethical Committee.

\section{Tumor cells}

EAC cells were obtained from Chittaranjan National Cancer Institute (CNCI), Kolkata, India. The EAC cells were maintained in vivo in Swiss albino mice by intraperitoneal transplantation of $2 \times 10^{6}$ cells per mouse after every 10 days. EAC cells 9 days old were used for the screening of antitumor activity of MEGP.

\section{Acute toxicity test}

The animals were divided into six groups containing eight animals in each group. MEGP was suspended in normal saline and administered orally as a single dose to groups of mice at different concentrations (500, 750, 1000, 1,250, 1,500 and 2,000 mg/kg body weight). These animals were observed for a $72 \mathrm{~h}$ period. The number of deaths was expressed as a percentile and the $\mathrm{LD}_{50}$ was determined by probit a test using the death percentage versus the log dose (Thompson and Weil, 1952).

\section{Short-term toxicity}

To determine short-term (14 days) toxicity, healthy Swiss albino mice were divided into 4 groups of 8 animals in each. Group 1 received normal saline $(5 \mathrm{ml} / \mathrm{kg}$ ), orally once daily for 14 days (vehicle control). Groups 2,3 and 4 received MEGP at the doses of 100, 250 and $500 \mathrm{mg} / \mathrm{kg}$ respectively, orally once daily for 14 days. At twenty-four hours after the last dose, and after $18 \mathrm{~h}$ fasting, the mice were sacrificed. Blood and liver were collected and important internal organs were removed, weighed and observed for pathological changes. Hematological parameters were determined as described above. Serum glutamate pyruvate transaminase (SGPT) and glutamate oxaloacetate transaminase (SGOT) were determined (Bergmeyer et al., 1978). Urea was estimated by the enzymatic method and calcium 
was estimated by the O-cresolphthalein complexone method (Tietz, 1987). Phosphorous was estimated by the colorimetric method (Henry, 1974). Liver biochemical parameters were estimated by the standard methods described above.

\section{Antitumor activity}

Male Swiss Albino mice were divided in to 6 groups $(n=12)$. All the groups were injected with EAC cells ( $0.2 \mathrm{ml}$ of $2 \times 10^{6}$ cells per mouse) intraperitonelly except the normal group. This was taken as day zero. On the first day, $5 \mathrm{ml} / \mathrm{kg}$ of normal saline was administered to group 1 and 2 (normal and EAC control). MEGP at different dose (100, 250 and $500 \mathrm{mg} / \mathrm{kg}$ ) and the standard drug 5-Fluorouracil $(20 \mathrm{mg} / \mathrm{kg}$ ) (Kavimani and Mani Senthilkumar, 2000) were administered in group 3, 4, 5 and 6 respectively for 14 days orally. After the last dose and $18 \mathrm{~h}$ fasting, six mice from each group were sacrificed for the study of antitumor activity, hematological and liver biochemical parameters. The rest of the animal groups were kept to check the survival time of EAC-tumor bearing hosts.

The antitumor activity of the methanol extract of Galega purpurea was measured in EAC animals with respect to the following parameters:

\section{Tumor volume}

The mice were dissected and the ascitic fluid was collected from the peritoneal cavity. The volume was measured by taking it in a graduated centrifuge tube and packed cell volume was determined by centrifuging at $100 \mathrm{rpm}$ per $5 \mathrm{~min}$.

\section{Tumor cell count}

The ascitic fluid was taken in a WBC pipette and diluted 100 times. Then a drop of the diluted cell suspension was placed on the Neubauer's counting chamber and the numbers of cells in the 64 small squares were counted.

\section{Viable/non-viable tumor cell count}

The cells were then stained with trypan blue $(0.4 \%$ in normal saline) dye. The cells that didn't take up the dye were viable and those that took the dye were non-viable. These viable and non-viable cells were counted.

Cell count $=$ Number of cells $\times$ dilution $/$ Area

$\times$ thickness of liquid film

\section{Percentage increase life span (\% ILS)}

The effect of MEGP on tumor growth was monitored by recording the mortality daily for a period of 6 weeks and percentage increase in life span (\% ILS) was calculated.

$\%$ ILS $=($ Mean survival of treated group $/$ Mean survival of control group) $-1 \times 100$

Mean survival $=($ Day of first death + day of last death) $/ 2$

\section{Body weight}

Body weight of the experimental mice were recorded both in the treated and control group at the beginning of the experiment (day 0) and sequentially on every $5^{\text {th }}$ day during the treatment period.

\section{Hematological parameters}

At the end of the experimental period, the next day after an over night fast blood was collected from freely flowing tail vein and used for the estimation Hemoglobin $(\mathrm{Hb})$ content, red blood cell count (RBC) (D'Armour et al., 1965) and white blood cell count (WBC) (Wintrobe et al., 1961). WBC differential count was carried out from Leishman stained blood smears (Dacie, 1958).

\section{Biochemical assays}

After the collection of the blood samples, the mice were sacrificed. Then their liver was excised, rinsed in ice-cold normal saline solution followed by cold $0.15 \mathrm{M}$ Tris-HCl ( $\mathrm{pH} 7.4$ ), blotted dry and weighed. A $10 \% \mathrm{w} / \mathrm{v}$ homogenate was prepared in $0.15 \mathrm{M}$ Tris- $\mathrm{HCl}$ buffer and was used for the 
estimation of lipid peroxidation (LPO) and reduced glutathione (GSH). The rest of the homogenate was centrifuged at $1,500 \mathrm{rpm}$ for $15 \mathrm{~min}$ at $4^{\circ} \mathrm{C}$ the supernatant thus obtained was used for the estimation of superoxide dismutase (SOD), catalase (CAT) and total protein.

\section{Estimation of lipid peroxidation (LPO)}

The levels of Thiobarbituric acid reactive substances (TBARS) in the liver were measured by the method of Ohkawa (1979) as a marker for lipid peroxidation. A mixture of $0.4 \mathrm{ml}$ of $10 \%$ liver homogenate, 1.5 $\mathrm{ml}$ of $8.1 \%$ sodium dodecyl sulphate (SDS), and 1.5 $\mathrm{ml}$ of $0.8 \%$ TBA solution was heated at $95^{\circ} \mathrm{C}$ for $1 \mathrm{~h}$. After cooling, $5.0 \mathrm{ml}$ of n-butanol-pyridine (15: 1) was added, and the absorbance of the n-butanolpyridine layer was measured at $532 \mathrm{~nm}$.

\section{Estimation of reduced glutathione (GSH)}

The tissue GSH was determined by the method of Beutler and Kelly (1963). Virtually all the nonprotein sulfhydryl groups of tissues are in the form of reduced GSH. $0.2 \mathrm{ml}$ of tissue homogenate was mixed with $1.8 \mathrm{ml}$ of EDTA solution. To this $3.0 \mathrm{ml}$ precipitation reagent (after precipitating proteins with TCA) was added, mixed thoroughly and kept for $5 \mathrm{~min}$ before centrifugation. To $2.0 \mathrm{ml}$ of the filtrate, $4.0 \mathrm{ml}$ of $0.3 \mathrm{M}$ disodium hydrogen phosphate solution and $1.0 \mathrm{ml}$ of DTNB reagent were added and the absorbance read at $412 \mathrm{~nm}$.

\section{Estimation of superoxide dismutase (SOD)}

The activity of SOD in tissue was assayed by the method of Kakkar (1984). The assay mixture contained $1.2 \mathrm{ml}$ sodium pyrophosphate buffer ( $\mathrm{pH} 8.3,0.025$ mol/l), $0.1 \mathrm{ml} \mathrm{PMS} \mathrm{(186} \mathrm{mmol/l),} 0.3 \mathrm{ml}$ nitroblue tetrazolium (300 mmol/l, $0.2 \mathrm{ml} \mathrm{NADH} \mathrm{(780} \mathrm{mmol/l)}$ and diluted enzyme preparation and water in a total volume of $3 \mathrm{ml}$. After incubation at $30^{\circ} \mathrm{C}$ for $90 \mathrm{~s}$, the reaction was terminated by the addition of $1.0 \mathrm{ml}$ of glacial acetic acid. The reaction mixture was stirred vigorously and shaken with $4.0 \mathrm{ml}$ $\mathrm{n}$-butanol. The color intensity of the chromogen in the butanol layer was measured at $560 \mathrm{~nm}$ against n-butanol.

\section{Estimation of catalase (CAT)}

Catalase was assayed according to the method of Maehly and Chance (1954). The estimation was done spectrophotometrically following the decrease in absorbance at $230 \mathrm{~nm}$. The tissue was homogenized in $\mathrm{M} / 150$ phosphate buffer $(\mathrm{pH} 7.0)$ at $4^{\circ} \mathrm{C}$ and centrifuged at 5,000 $\mathrm{rpm}$. The reaction mixture contained $0.01 \mathrm{M}$ phosphate buffer ( $\mathrm{pH} 7.0$ ), $2 \mathrm{mM}$ $\mathrm{H}_{2} \mathrm{O}_{2}$ and the enzyme extract. The specific activity of catalase is expressed in terms of units/mg protein. A unit is defined as the velocity constant per second.

\section{Estimation of total proteins}

The protein content of tissue homogenates was measured by the method of Lowry (1951). $0.5 \mathrm{ml}$ of tissue homogenate was mixed with $0.5 \mathrm{ml}$ of $10 \%$ TCA and centrifuged for $10 \mathrm{~min}$. The precipitate obtained was dissolved in $1.0 \mathrm{ml}$ of $0.1 \mathrm{~N} \mathrm{NaOH}$. From this an aliquot was taken for protein estimation. $0.1 \mathrm{ml}$ of aliquot was mixed with $5.0 \mathrm{ml}$ of alkaline copper reagent and allowed to stand at room temperature for $10 \mathrm{~min}$. $0.5 \mathrm{ml}$ of Folin's phenol reagent was added and the blue color developed was read after $20 \mathrm{~min}$ at $640 \mathrm{~nm}$.

\section{Statistical analysis}

The experimental results were expressed as mean \pm S.E.M. Data were assessed by ANOVA followed by the Student t-test; $P<0.05$ was considered as statistically significant.

\section{RESULTS}

\section{Acute toxicity study}

In the acute toxicity assay no deaths were observed during the $72 \mathrm{~h}$ period at the doses tested. At these doses, the animals showed no stereotypical symptoms associated with toxicity, such as convulsion, ataxy, diarrhoea or increased diuresis. The median lethal 
dose $\left(\mathrm{LD}_{50}\right)$ was determined to be higher that highest dose tested i.e., $2.0 \mathrm{~g} / \mathrm{kg}$.

\section{Short-term toxicity}

When the mice were observed for the behavioral changes after oral administration of a single dose of the extract none of the mice were exhibited any abnormal behavioral responses at the doses of 100, 250 and $500 \mathrm{mg} / \mathrm{kg}$. Administration of repeated daily doses of 100, 250 and $500 \mathrm{mg} / \mathrm{kg}$ for 14 days did not influence the bodyweight of the mice. The weights of liver, kidney, brain and spleen were also not altered by the treatment. Hematological parameters like hemoglobin and RBC count remained unaltered at the dose of 100, 250 and 500 $\mathrm{mg} / \mathrm{kg}$. But there was a marginal increase in WBC count. The results were summarized in Table 1.

\section{Effect of MEGP on mean survival time}

The effect of MEGP at the doses of 100, 250 and 500 $\mathrm{mg} / \mathrm{kg}$ on the mean survival time of EAC bearing mice is shown in Table 2. In the EAC control group the mean survival time was $21.03 \pm 0.12$, while it increased to $28.35 \pm 0.02(100 \mathrm{mg} / \mathrm{kg}), 32.43 \pm 0.6$
$(250 \mathrm{mg} / \mathrm{kg})$ and $35.22 \pm 0.4(500 \mathrm{mg} / \mathrm{kg})$ days respectively in the MEGP treated groups. The group treated with the standard drug 5-Fluorouracil $(20 \mathrm{mg} / \mathrm{kg}$ ) shows $39.54 \pm 0.25$ days for the same.

\section{Effect of MEGP on tumor growth}

The tumor volume, packed cell volume and viable cell count were found to be significantly $(P<0.01)$ increased and non-viable cell count was significantly $(P<0.01)$ low in EAC control animals when compared with normal control animals. Administration of MEGP at the doses of 100, 250 and $500 \mathrm{mg} / \mathrm{kg}$ significantly $(P<0.01)$ decreased the tumor volume, packed cell volume and viable cell count. Further more, non-viable tumor cell count at different doses of MEGP was significantly $(P<0.01)$ increased in a dose dependent manner. Finally, the change in body weights of the animals suggests the tumor growth inhibiting property of MEGP. All these results clearly indicate that the MEGP has a remarkable capacity to inhibit the growth of solid tumor induced by EAC cell line in a dose dependent manner in experimental animals (Table 2).

Table 1. Effect of methanol extract of Galega purpurera (MEGP) on hematological, biochemical parameters and body weight of normal mice

\begin{tabular}{|c|c|c|c|c|}
\hline Parameters & $\begin{array}{c}\text { Normal } \\
(0.9 \% \mathrm{NaCl}, 5 \mathrm{ml} / \mathrm{kg})\end{array}$ & $\begin{array}{c}\text { MEGP } \\
(100 \mathrm{mg} / \mathrm{kg})\end{array}$ & $\begin{array}{c}\text { MEGP } \\
(250 \mathrm{mg} / \mathrm{kg})\end{array}$ & $\begin{array}{c}\text { MEGP } \\
(500 \mathrm{mg} / \mathrm{kg})\end{array}$ \\
\hline Hemoglobin (g \%) & $11.6 \pm 0.22$ & $10.2 \pm 0.03$ & $10.3 \pm 0.01$ & $10.8 \pm 0.03$ \\
\hline $\operatorname{RBC}\left(10^{6} / \mathrm{mm}^{3}\right)$ & $6.4 \pm 0.41$ & $6.5 \pm 0.2^{\mathrm{a}}$ & $6.1 \pm 0.1$ & $6.7 \pm 0.04$ \\
\hline Total WBC $\left(10^{6} / \mathrm{mm}^{3}\right)$ & $5.2 \pm 0.51$ & $6.2 \pm 0.05$ & $6.9 \pm 0.2$ & $7.1 \pm 0.14$ \\
\hline SGPT (U/L) & $65.1 \pm 0.25$ & $68.3 \pm 0.3^{\mathrm{b}}$ & $73.8 \pm 0.02$ & $75.1 \pm 0.15^{\mathrm{b}}$ \\
\hline SGOT (U/L) & $39.5 \pm 0.03$ & $43.6 \pm 0.02$ & $45.3 \pm 0.08$ & $48.4 \pm 0.23$ \\
\hline Serum urea (mg/dl) & $22.6 \pm 2.8$ & $20.9 \pm 2.04$ & $21.4 \pm 0.09^{\mathrm{b}}$ & $23.0 \pm 0.06$ \\
\hline Serum calcium (mg/dl) & $10.1 \pm 5.9$ & $10.1 \pm 0.04$ & $10.4 \pm 0.12$ & $10.6 \pm 0.04$ \\
\hline Serumphosphate $(\mathrm{mg} / \mathrm{ml})$ & $4.2 \pm 4.7$ & $4.6 \pm 0.01$ & $4.8 \pm 0.03$ & $5.3 \pm 0.15^{\mathrm{b}}$ \\
\hline LPO (nmolMDA/mg protein) & $0.94 \pm 0.41$ & $0.89 \pm 0.7$ & $0.92 \pm 0.04$ & $0.90 \pm 0.11$ \\
\hline GSH (mg/g wet tissue) & $2.33 \pm 0.68$ & $2.48 \pm 0.29$ & $2.52 \pm 0.26^{\mathrm{c}}$ & $2.57 \pm 0.24$ \\
\hline SOD (U/mg protein) & $4.47 \pm 0.21$ & $4.55 \pm 0.4$ & $4.60 \pm 0.5$ & $4.71 \pm 0.17$ \\
\hline CAT (U/mg protein) & $26.2 \pm 0.44$ & $27.68 \pm 0.2^{\mathrm{b}}$ & $28.7 \pm 0.23$ & $29.1 \pm 0.5^{\mathrm{b}}$ \\
\hline Body weight (g) & $21.5 \pm 0.25$ & $21.8 \pm 0.3$ & $22.8 \pm 0.2$ & $21.7 \pm 0.3$ \\
\hline
\end{tabular}

Data are expressed as the mean of results in 8 mice \pm S.E.M. ${ }^{\mathrm{a}} P<0.05 ;{ }^{\mathrm{b}} P<0.01 ;{ }^{\mathrm{c}} P<0.001$ Experimental groups compared with the normal group. 
Table 2. Effect of methanol extract of Galega purpurera (MEGP) on body weight, mean survival time, \% ILS, tumor volume, packed cell volume and viable and non-viable tumor cell count of EAC bearing mice

\begin{tabular}{lccccc}
\hline Parameters & $\begin{array}{c}\text { EAC control } \\
\left(2 \times 10^{6} \text { cells/ml/mouse }\right)\end{array}$ & $\begin{array}{c}\text { EAC }+ \text { MEGP EAC + MEGP EAC + MEGP EAC + 5-FU } \\
(100 \mathrm{mg} / \mathrm{kg})\end{array}$ & $(250 \mathrm{mg} / \mathrm{kg})$ & $(500 \mathrm{mg} / \mathrm{kg})$ & $(20 \mathrm{mg} / \mathrm{kg})$ \\
\hline Body weight $(\mathrm{g})$ & $27.5 \pm 0.25$ & $26.48 \pm 0.01^{\mathrm{b}}$ & $25.73 \pm 0.09$ & $22.41 \pm 0.07^{\mathrm{b}}$ & $21.94 \pm 0.3^{\mathrm{b}}$ \\
Mean Survival Time (days) & $21.03 \pm 0.12$ & $28.35 \pm 0.02^{\mathrm{b}}$ & $32.43 \pm 0.6^{\mathrm{b}}$ & $35.22 \pm 0.4^{\mathrm{b}}$ & $36.54 \pm 0.25^{\mathrm{b}}$ \\
Increase Life Span $(\%)$ & - & 34.81 & 54.21 & 67.48 & 73.75 \\
Tumor volume $(\mathrm{ml})$ & $3.96 \pm 0.03$ & $3.31 \pm 0.1^{\mathrm{b}}$ & $2.23 \pm 0.31^{\mathrm{b}}$ & $1.0 \pm 0.42^{\mathrm{b}}$ & - \\
Packed cell volume (ml) & $2.14 \pm 0.06$ & $1.26 \pm 0.3$ & $0.82 \pm 0.21$ & $0.27 \pm 0.2^{\mathrm{b}}$ & - \\
$\begin{array}{l}\text { Viable tumor cell count } \\
\left(\times 10^{7} \text { cells/ml) }\right.\end{array}$ & $10.41 \pm 0.06$ & $6.35 \pm 0.03$ & $3.21 \pm 0.12$ & $2.30 \pm 0.5$ & $0.9 \pm 0.13^{\mathrm{b}}$ \\
$\begin{array}{l}\text { Non-viable tumor cell count } \\
\left(\times 10^{7} \text { cells } / \mathrm{ml}\right)\end{array}$ & $0.97 \pm 0.05$ & $1.76 \pm 0.01^{\mathrm{b}}$ & $1.12 \pm 0.03^{\mathrm{b}}$ & - & - \\
\hline
\end{tabular}

Data are expressed as the mean of results in 6 mice \pm S.E.M. ${ }^{b} P<0.01$ Experimental groups compared with the EAC control group. Body weight of normal mice is $21.8 \pm 0.19$.

Table 3. Effect of methanol extract of Galega purpurera (MEGP) on hematological parameters of EAC bearing mice

\begin{tabular}{|c|c|c|c|c|c|c|}
\hline Parameters & $\begin{array}{c}\text { Normal (0.9\% } \\
\mathrm{NaCl}, 5 \mathrm{ml} / \mathrm{kg})\end{array}$ & $\begin{array}{c}\text { EAC control } \\
\left(2 \times 10^{6} \text { cells } /\right. \\
\mathrm{ml} / \text { mouse })\end{array}$ & $\begin{array}{l}\text { EAC+MEGP } \\
(100 \mathrm{mg} / \mathrm{kg})\end{array}$ & $\begin{array}{l}\text { EAC+MEGP } \\
(250 \mathrm{mg} / \mathrm{kg})\end{array}$ & $\begin{array}{l}\text { EAC+MEGP } \\
(500 \mathrm{mg} / \mathrm{kg})\end{array}$ & $\begin{array}{l}\text { EAC+5 -FU } \\
(20 \mathrm{mg} / \mathrm{kg})\end{array}$ \\
\hline Hemoglobin (g \%) & $13.6 \pm 0.8$ & $10.65 \pm 1.5^{\mathrm{c}}$ & $11.61 \pm 1.1^{b}$ & $12.34 \pm 0.66^{\mathrm{b}}$ & $12.99 \pm 0.42^{\mathrm{b}}$ & \\
\hline RBC (cells/ml $\subset 10^{6}$ ) & $5.43 \pm 1.5$ & $3.96 \pm 1.3^{c}$ & $4.30 \pm 1.6$ & $4.42 \pm 0.35^{\mathrm{b}}$ & $5.33 \pm 0.37^{\mathrm{b}}$ & $4.97 \pm 1.5^{\mathrm{b}}$ \\
\hline WBC (cells $/ \mathrm{ml} \notin 10^{6}$ ) & $8.22 \pm 1.2$ & $16.54 \pm 1.1^{\mathrm{c}}$ & $13.52 \pm 1.2^{\mathrm{b}}$ & $10.4 \pm 0.80^{\mathrm{b}}$ & $8.15 \pm 0.50$ & $8.53 \pm 1.2^{\mathrm{b}}$ \\
\hline Monocytes (\%) & & $1.59 \pm 1.4^{\mathrm{c}}$ & & $1.91 \pm 0.12$ & $2.08 \pm 0.55$ & $2.15 \pm 0.5$ \\
\hline Lymphocytes (\%) & $72.63 \pm 1.5$ & $37.26 \pm 1.6^{\mathrm{c}}$ & & $60.01 \pm 0.40^{\mathrm{b}}$ & $66.17 \pm 0.22$ & $70.14 \pm 0.8^{\mathrm{b}}$ \\
\hline Neutrophils (\%) & $25.41 \pm 0.1$ & $64.14 \pm 1.0^{c}$ & $39.34 \pm 0.32$ & $42.27 \pm 0.21^{\mathrm{b}}$ & $30.53 \pm 0.35^{\mathrm{b}}$ & $29.52 \pm 1.5$ \\
\hline
\end{tabular}

Data are expressed as the mean of results in 6 mice \pm S.E.M. ${ }^{b} P<0.01$ Experimental groups compared with the EAC control group, ${ }^{c} P<0.001$ Experimental groups compared with the normal group.

\section{Effect of MEGP on hematological parameters}

The effect of MEGP on hematological parameters of EAC treated animals were shown in Table 3. Hematological parameters of tumor bearing mice on day 14 were found to be significantly altered compared to the normal group. The hemoglobin content and RBC count in the EAC control group was significantly $(P<0.001)$ decreased as compared to the normal group. Treatment with MEGP at the dose of 100, 250 and $500 \mathrm{mg} / \mathrm{kg}$ significantly $(P<$ 0.01 ) increased the hemoglobin content and RBC count to more or less normal levels. The total WBC counts and protein was found to be increased significantly in the EAC control group when compared with normal group $(P<0.001)$. Administration of MEGP at the doses of 100, 250 and $500 \mathrm{mg} / \mathrm{kg}$ to EAC bearing mice significantly $(P<0.01)$ reduced the WBC count and protein as compared with the EAC control animals. In differential count of WBC the percentage of neutrophils increased while the lymphocyte count decreased in the EAC control group. Treatment with MEGP at different doses changed these altered parameters towards more or less normal values.

\section{Effect of MEGP on lipid peroxidation}

The localization of radical formation resulting in lipid peroxidation, measured as malondialdehyde (MDA) in mice liver homogenate is shown in Figure 1. The increased MDA levels in EAC treated animals (1.47 nmol MDA/mg protein) were reduced by MEGP at the dose of 100, 250 and $500 \mathrm{mg} / \mathrm{kg}$ 


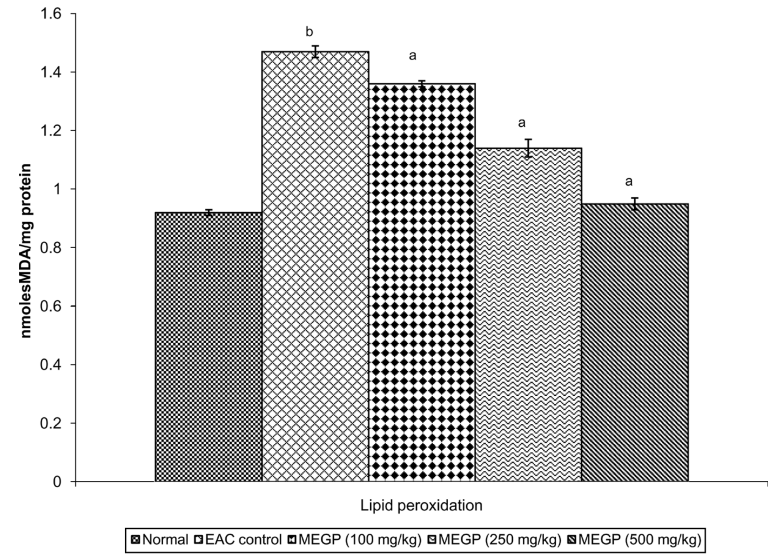

Fig. 1. Effect of methanol extract of Galega purpurea (MEGP) on hepatic lipid peroxidation level in EACbearing mice.

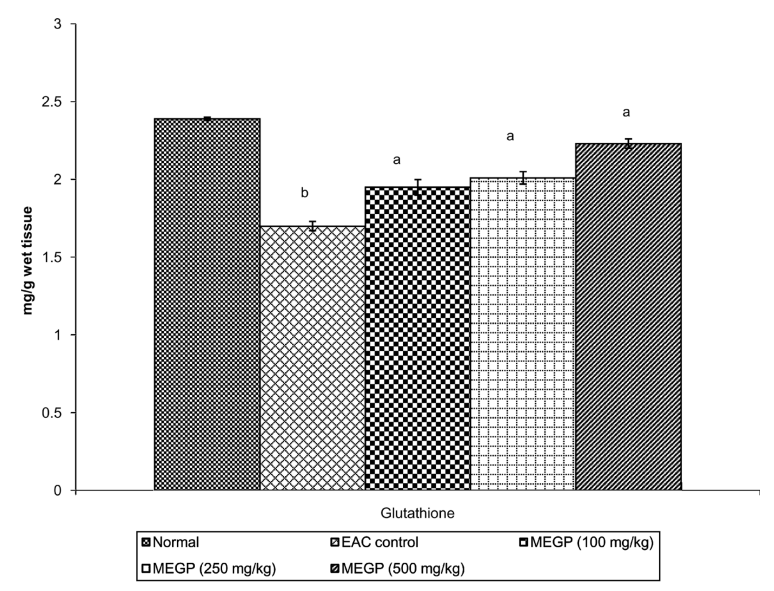

Fig. 2. Effect of methanol extract of Galega purpurea (MEGP) on hepatic glutathione content in EACbearing mice.

by $1.36,1.14$ and $0.95 \mathrm{nmol} \mathrm{MDA} / \mathrm{mg}$ protein respectively.

\section{Effect of MEGP on glutathione level}

The effect of MEGP on glutathione content in the liver is shown in Fig. 2. GSH level in normal group was $2.39 \mathrm{mg} / \mathrm{g}$ of liver whereas that of EAC treated group was $1.7 \mathrm{mg} / \mathrm{g}$ wet tissue. GSH level increased by MEGP at the dose of 100, 250 and 500 $\mathrm{mg} / \mathrm{kg}$ were 1.95, 2.01 and $2.23 \mathrm{mg} / \mathrm{g}$ of liver respectively.

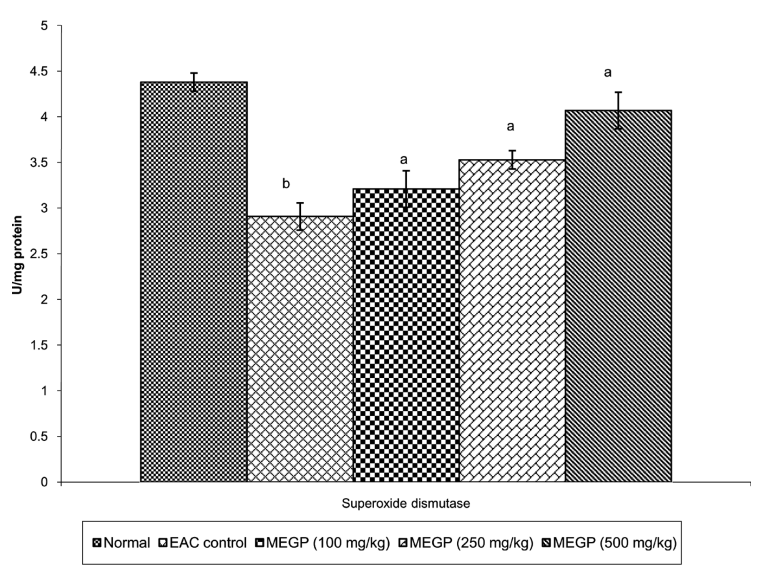

Fig. 3. Effect of methanol extract of Galega purpurea (MEGP) on hepatic SOD activity in EAC-bearing mice.

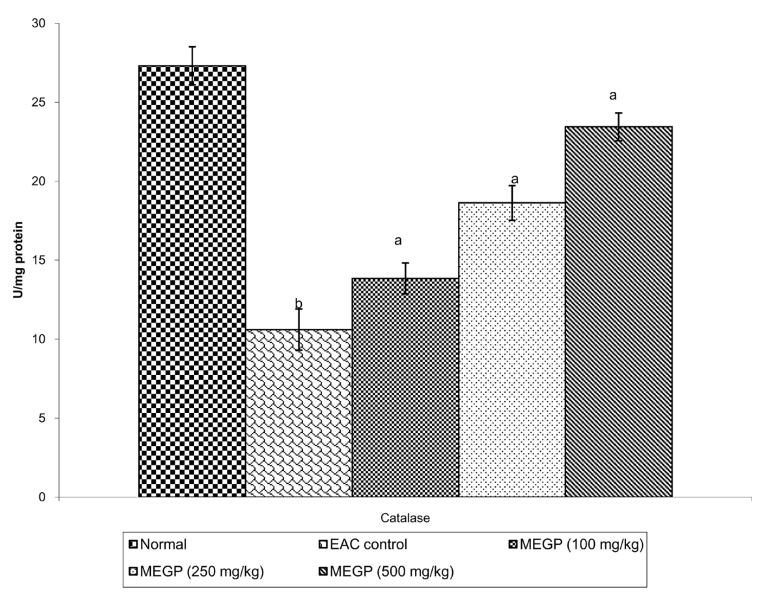

Fig. 4. Effect of methanol extract of Galega purpurea (MEGP) on hepatic CAT activity in EAC-bearing mice.

\section{Effect of MEGP on SOD activity}

The effect of MEGP on SOD activity in liver is shown in Fig. 3. The SOD level was decreased in EAC treated animals to $2.91 \mathrm{U} / \mathrm{mg}$ protein. The SOD levels were increased to 3.21, 3.53 and 4.07, $39.65 \mathrm{U} / \mathrm{mg}$ protein respectively by the treatment of MEGP at the dose of 100, 250 and $500 \mathrm{mg} / \mathrm{kg}$.

\section{Effect of MEGP on catalase activity}

CAT activities in the liver homogenate were shown in Fig. 4. CAT activity of total liver homogenate of EAC treated group and normal group were 10.6 and $27.3 \mathrm{U} / \mathrm{mg}$ protein respectively. Treatment of 
MEGP at the dose of 100, 250 and $500 \mathrm{mg} / \mathrm{kg}$ increased the liver CAT activities to 13.84, 18.63 and $23.44 \mathrm{U} / \mathrm{mg}$ protein respectively.

\section{DISCUSSION}

In the present manuscript we have shown the in vivo antitumor and antioxidant status of Galega purpurea extract in EAC bearing mice. The MEGP treated animals at the doses of 100, 250 and 500 $\mathrm{mg} / \mathrm{kg}$ significantly inhibited the tumor volume, packed cell volume, tumor cell count and brought back the hematological parameters to more or less normal levels. The extract also restored the hepatic lipid peroxidation and free radical scavenging enzyme GSH as well as antioxidant enzymes such as SOD and CAT in tumor bearing mice to near normal levels. Short-term toxicity studies indicate that MEGP at the doses of 100, 250 and $500 \mathrm{mg} / \mathrm{kg}$ for 14 days did not exhibit any adverse effects.

In EAC bearing mice a regular rapid increase in ascites tumor volume was noted. Ascites fluid is the direct nutritional source to tumor cells and rapid increase in ascitic fluid with tumor growth could be a means to meet the nutritional requirements of tumor cells (Prasad and Giri, 1994). Treatment with MEGP inhibited the tumor volume, tumor cell count and increased the percentage of trypan blue positive stained dead cells in tumor bearing mice. The reliable criteria for judging the value of any anticancer drug are the prolongation of life span of animals (Clarkson and Burchenal, 1965) and disappearance of leukemic cells from blood (Feninger and Mider, 1954). A decrease in tumor volume and viable tumor cell count as mentioned above finally reduced the tumor burden and enhanced the life span of EAC bearing mice.

The major problems encountered in cancer chemotherapy are of myelosupression and anemia (Price and Greenfild, 1958; Hogland, 1982). The anemia encountered in tumor bearing mice is mainly due to reduction in RBC or hemoglobin percentage and this may occur either due to iron deficiency or due to hemolytic or myelopathic conditions (Feninger and Mider, 1954). Perturbation of hematological parameters in tumor bearing animals is partly due to the toxic effects produced in them. In addition myelosupression in cancer chemotherapy is a common phenomenon, which is responsible for poor prognosis (Donehower, 1990). Treatment with MEGP brought back the hemoglobin content, RBC and WBC cell count near to normal levels. This indicates that MEGP possess protective action on the hemopoietic system.

Excessive production of free radicals resulted in oxidative stress, which leads to damage of macromolecules such as lipids can induce lipid peroxidation in vivo (Yagi, 1987). Increased lipid peroxidation would cause degeneration of tissues. Lipid peroxidase formed in the primary site would be transferred through the circulation and provoke damage by propagating the process of lipid peroxidation (Sinclair, 1990). Malondialdehyde (MDA), the end product of lipid peroxidation was reported to be higher in cancer tissues than in nondiseased organs (Yagi, 1987). Glutathione, a potent inhibitor of neoplastic process plays an important role as an endogenous antioxidant system. It is found particularly in high concentration in liver and is known to have a key function in the protective process (Sinclair, 1990). MEGP reduced the elevated levels of lipid peroxidation and increased the glutathione content in EAC bearing mice.

SOD and CAT, the free radical scavenging system are present in all oxygen-metabolizing cells and their function is to provide a defense against the potentially damaging reactivities of superoxide and hydrogen peroxide. A decrease in SOD activity in EAC bearing mice which might be due to loss of Mn SOD activity in EAC cells and the loss of mitochondria leading to a decrease in total SOD activity in the liver (Sun et al., 1989).

The inhibition of SOD and CAT activities as a result of tumor growth was also reported (Marklund et al., 1982). Similar findings were observed in the present investigation with EAC bearing mice. The 
administration of MEGP at different doses increased the SOD and CAT levels in a dose dependent manner, which may indicate the antioxidant and free radical scavenging property of MEGP.

It was reported that plant-derived extracts containing antioxidant principles showed cytotoxicity towards tumor cells (Jiau-Jian and Larry, 1977) and antitumor activity in experimental animals (Ruby et al., 1995). Antitumor activity of these antioxidants in either through induction of apoptosis (Ming et al., 1998) or by inhibition of neovascularization (Putul et al., 2000). The lowering of lipid peroxidation and increase in levels of GSH, SOD and CAT in MEGP treated group indicates its potential as an inhibitor of EAC induced intracellular oxidative stress.

The present study demonstrates the MEGP increased the life span of EAC tumor bearing mice and decreased lipid peroxidation and thereby augmented the endogenous antioxidant enzymes in the liver. All these parameters suggest that the methanol extract of Galega purpurea root exhibits potential antitumor and antioxidant activities. Further investigation are in progress in our laboratory to identify the active principles involved in this antitumor and antioxidant activity.

\section{REFERENCES}

Bergmeyer HU, Scheibe P, Wahlefeld AW. (1978) Optimization of methods for aspartate aminotransferase and alanine aminotransferase. Clin. Chem. 24, 58-61.

Beulter E, Kelly BM. (1963) The effect of sodium nitrate on rd cell glutathione. Experientia. 18, 96-97.

Clarkson BD, Burchenal JH. (1965) Preliminary screening of antineoplastic drugs. Prog. Clin. Cancer 1, 625-629.

D'Armour FE, Blood FR, Belden DA. (1965). The manual for laboratory work in mammalian physiology, pp. 4-6, $3^{\text {rd }}$ ed, The University of Chicago Press, Chicago.

Dacie JV, Lewis SM. (1958) Practical hematology, pp. 38-48, $2^{\text {nd }}$ ed, J and A Churchill, London.

Donehower RC. (1990) Hydroxy urea. In: Cancer Chemotherapy, Principles and Practice, pp. 225-233, ed by JM Chabner, JM Collins, JB Lippincott co, Philadelphia.

Feninger LG, Mider DB. (1954) Advances in cancer Research, Vol II, pp. 353-354, Academic Press, New York.

Fenninger LD, Mider GB. (1954) Energy and nitrogen metabolism in cancer. Adv. Cancer Res. 2, 229-253.

Henry RS. (1974) Clinical chemistry, Principles and techniques, pp. 285-299, Harper and Row, New York.

Hogland HC. (1982) Hematological complications of cancer chemotherapy. Semin. Oncol. 9, 95-102.

Jiau-Jian L, Larry WO. (1977) Over expression of manganese containing superoxide dismutase confers resistance to the cytotoxicity of tumor necrosis factor a and/ or hypothermia. Cancer Res. 57, 1991-1998.

Kakkar P, Das B, Vishwanathan PN. (1984) A modified spectrophotometric assay of superoxide dismutase. Indian J. Biochem. Biophys. 21, 130-132.

Kavimani S, Manisenthil Kumar KT. (2000) Effect of methanol extract of Enicostemma littorale on Dalton's lymphoma. J. Ethnopharmacol. 71, 349-352.

Lowry OH, Rosebrough NJ, Farr AL, Randall RJ. (1951) Protein measurement with he Folin-phenol reagent. J. Biol. Chem 193, 265-275.

Maehly AC, Chance B. (1954) Methods of Biochemical Analysis, Vol. I, pp. 357, editor Glick D, Interscience, New York.

Marklund SL, Westman NG, Lundgren E, Roos G. (1982) Copper and zinc containing superoxide dismutase, catalase and glutathione peroxidase in normal and neoplastic humal cell lines and normal human tissues. Cancer Res. 42, 1955-1961.

Ming L, Jill CP, Jingfang JN, Edward C, Brash E. (1998) Antioxidant action via p53 mediated apoptosis. Cancer Res. 58, 1723-1729.

Nadkarni KM. (1976) Indian Materia Medica Vol I, pp. 561-563, Popular Prakashan, Bombay.

Ohkawa H, Onishi N, Yagi K. (1979) Assay for lipid peroxidation in animal tissue by thibarbituric acid reaction. Anal. Biochem. 95, 351-358.

Prasad SB, Giri A. (1994) Antitumor effect of cisplatin against murine ascites Dalton's lymphoma. Indian J. Exp. Biol. 32, 155-162.

Price VE, Greenfild RE. (1958) Anemia in cancer. Adv. Cancer Res. 5, 199-200.

Putul M, Sunit C, Pritha B. (2000) Neovascularisation offers a new perspective to glutamine -related 
therapy. Indian J. Exp. Biol. 38, 88-90.

Ruby AJ, Kuttan G, Babu KD, Rajasekaran KN, Kuttan R. (1995) Antitumor and antioxidant activity of natural curcuminoids. Cancer Lett. 94, 783-789.

Sinclair AJ, Barnet AH, Lunie J. (1990) Free radical and auto-oxidant systems in health and disease. $\mathrm{Br}$. J. Hosp. Med. 43, 334-344.

Sun Y, Oberley LW, Elwell JH, Sierra RE. (1989) Antioxidant enzyme activities in normal and transformed mice liver cells. Int. J. Cancer 44, 10281033.
Thompson WR, Weil CS. (1952) On the construction of tables for moving average interpolations. Biometrics 8, 51-54.

Tietz NW. (1987) Fundamentals of clinical chemistry pp. $75,3^{\text {rd }}$ ed, WB Saunders Company, Philadelphia.

Wntrobe MM, Lee GR, Boggs DR, Bithel TC, Athens JW, Foerester J. (1961) Clinical Hematology, pp. 326, $5^{\text {th }}$ ed, Philadelphia.

Yagi K. (1987) Lipid peroxides and human diseases. Chem. Phys. Lipids 45, 337-351. 